\title{
A yeast-based model system for cloning secreted and membrane proteins
}

\author{
MARCELO J. SURPILI ${ }^{1}$, BERND MÜLLER-RÖBER ${ }^{2}$ and LOTHAR WILLMITZER ${ }^{2}$ \\ ${ }^{1}$ Institut für Genbiologische Forschung Berlin GmbH, Ihnestraße 63, 14195 Berlin, Germany \\ ${ }^{2}$ Max-Planck-Institut für molekulare Pflanzenphysiologie (MPI-MOPP), Karl-Liebknecht-Straße 25 \\ Haus 20, 14476 Golm, Germany
}

Manuscript received on March 15, 2002; accepted for publication on July 31, 2002; presented by LEWIS J. GREENE

\begin{abstract}
The targeting of proteins to cell organelles and membranes, or of proteins destined to secretion, is coordinated by signal sequences located at the $5^{\prime}$-end of their respective genes. A signal sequence trap system was envisaged in which a truncated version of the yeast acid phosphatase pho5 gene lacking the start codon and signal sequence could serve as a reporter gene. A fraction enriched in $5^{\prime}$-end fragments obtained by PCR from a potato guard-cell cDNA library was cloned in frame to the acid phosphatase gene and the acid phosphatase activity was assayed directly in yeast colonies grown on selective medium. Putative signal sequences targeting the acid phosphatase to the membrane or to the outside of the cell were used to screen the cDNA bank in order to recover the original full-size sequence which gave rise to the signal sequence. Two unknown sequences displaying marked tissue-specific expression were retrieved, one of them (YE139) with a higher expression level in green buds and stem cells, and the other one (YE290) with a higher expression level in androceum, gyneceum, and roots. The limitations of the system are further analyzed using other sequences as control.
\end{abstract}

Key words: signal sequences, potassium channel, yeast acid phosphatase, library screening.

\section{INTRODUCTION}

The partitioning of biochemical processes in organelles of eukaryotic cells is one of the major accomplishments of nature. Major targets for the partitioning of proteins in eukaryotes include mitochondria, chloroplasts, peroxisomes, glyoxysomes, and the nucleus. Proteins destined to these organelles are translated on free polyribosomes in the cytosol and, concomitantly or shortly thereafter, they are imported into the appropriate organelle based on the

Correspondence to: Marcelo J. Surpili

Laboratório Nacional de Luz Síncroton, LNLS

Rua Giuseppe Máximo Scolfano, 10.000

Cx. Postal 6192, 13084-971, Campinas, SP, Brazil

E-mail: msurpili@lnls.br recognition of specific targeting signals. In contrast, the transport of proteins to the cell membrane for insertion or secretion occurs by a default secretory pathway, in which the targeted protein moves from the endoplasmic reticulum (ER) to the Golgi apparatus, and then to transport vesicles (Hadlington and Denecke 2000). Whether a protein remains bound to the membrane or is secreted depends on its signal sequence.

Studies on the biosynthesis of secretory proteins in prokaryotes and eukaryotes have shown that most of these proteins are synthesized as precursors containing an additional of 15-30 amino acids at the N-terminal end of the molecule (Milstein et al. 1982). These transient $\mathrm{N}$-terminal extensions, 
known as signal peptides (Blobel and Dobberstein 1975), are responsible for most of the protein sorting that occurs in the cell.

Many membrane proteins on the inner and outer surface of the cell membrane have an important role in responding to changes in the external environment (Smith 1990). In plants, the greatest changes in the plasma membrane protein profile occur during the early stages of development, including floral induction and, to a lesser extent, in later stages such as seed formation and senescence. These temporal and spatial changes have been studied in detail in highly purified tobacco leaf plasma membrane fractions (Masson and Rossignol 1995).

The aim of the present study was to establish a system for screening cDNA libraries to trap signal sequences from proteins trafficking along the secretory pathway. The approach consisted of substituting the signal sequence of a known secretory protein for unknown sequences obtained preferentially from the $5^{\prime}$-ends of the library cDNA clones, where signal sequences are usually found. The signal sequences would then be recovered and used as probes to screen the cDNA bank for the full-size clone. The secretory protein chosen as a reporter in this case was the acid phosphatase PHO5 (E. C. 3.1.3.2) from Saccharomyces cerevisiae, the main enzyme in a family of four acid phosphatases in this yeast (Oshima 1997). Gene fusions to pho5 provide a convenient system for analyzing gene regulation, and for studying the signals involved in the proper localization of proteins in yeast (Sidhu and Bollon 1987, Lopandic et al. 1987). Arima et al. (1983) identified a 17-amino acid signal peptide in the repressible pho5 gene. In the present study, yeast PHO5 mutants were used, and shuttle vectors containing a truncated version of the pho5 gene, i.e., the nucleotide sequence corresponding to the protein without its native signal sequence, were constructed. The constructs containing unknown sequences in front of the truncated pho5 gene were then used for the transformation and partial complementation of mutant cells on adequate medium. PHO5 activity was detected by direct staining of yeast colonies grown on a plate using diazo-coupling dyes. The red diazocompound complex formed during the reaction cannot enter the cytoplasm, so the reaction must occur outside the cell. The presence of acid phosphatase outside the cell would thus indicate that a signal sequence was responsible for its secretion.

\section{MATERIALS AND METHODS}

\section{ENZYMES AND CHEMICALS}

DNA restriction and modification enzymes were purchased from Boehringer (Mannheim, Germany) and New England Biolabs (Beverly, MA). Chemicals were from Sigma (Deisenhofen, Germany), Boehringer (Mannheim, Germany) or Merck (Darmstadt, Germany). Primers T3 (5'-AATTAACCCTCACTAAAGGG) and T7 (5'-GTAATACGACTCACTATAGGGC) were purchased from LKB Pharmacia. All other primers for sequencing or PCR reactions were purchased from TibMolBiol, Berlin, Germany.

\section{Plants, Bacterial AND Yeast STRAins}

AND GROWTH CONDITIONS

Solanum tuberosum L. cv. Désirée was obtained from Saatzucht Fritz Lange GmbH (Bad Schwartau, Germany). The plants were grown in a greenhouse in individual pots and were watered daily with $\sim 16 \mathrm{~h}$ light $\left(22^{\circ} \mathrm{C}\right)$ and $8 \mathrm{~h}$ dark $\left(15^{\circ} \mathrm{C}\right)$ cycles.

Escherichia coli was cultured at $37^{\circ} \mathrm{C}$ in LuriaBertani medium using standard methods (Sambrook et al. 1989). E. coli strains DH5 $\alpha$ (Bethesda Research Laboratories, Gaithersburgh, MD, USA) and XL-1 Blue (Stratagene) were used for DNA cloning and screening experiments.

The Saccharomyces cerevisiae phosphatase mutant strain YHH-33 (his3-11,15; leu2-3,112; pho5) was kindly supplied by Dr. Meyhack (CibaGeigy, Basel, Switzerland). Stock cells were maintained on solid Yeast Nitrogen Base (YNB) medium containing the amino acids necessary for complementation. Transformed cells were plated on defined YNB medium without leucine (complementation present in the 181A1NE vector). 
PCR AMPLIFICATION OF THE PHO5 GENE FROM Saccharomyces cerevisiae

Genomic yeast DNA was isolated according to Rose et al. (1990) and used as a template in the PCR reactions to amplify the DNA sequence coding for the mature PHO5 enzyme. The reactions were done in a Perkin Elmer Cetus thermocycler using PHO1 (5' - GCTAGGATCCGGTACCATTCCCTTAGGCAAACTAGCC) and PHO2 (5'- GCTAAGATCTTTATTGTTTTAATAGGGTATCA) as forward and reverse primers, respectively. The former was complementary to the $5^{\prime}$-end of the pho5 gene coding region, without the PHO5 start codon and signal sequence. Primer $\mathrm{PHO} 2$ was complementary to a stretch of $38 \mathrm{bp}$ including the pho5 stop codon. Both primers introduced additional restriction sites at the ends of the amplified DNA (BamHI for primer $\mathrm{PHO} 1$ and $B g l \mathrm{II}$ for primer $\mathrm{PHO} 2)$. The following temperature profile ( 40 cycles) was used for amplification: denaturation, $94^{\circ} \mathrm{C} / 2 \mathrm{~min}$; primer annealing, $50^{\circ} \mathrm{C} / 1.5 \mathrm{~min}$; primer extension, $72^{\circ} \mathrm{C} /$ $2.5 \mathrm{~min}$.

\section{CONSTRUCTION OF THE SIGNAL SEQUENCE TRAP (SST) VECTOR (PSDEP-0)}

For construction of the SST vector, the coding region of the yeast pho5 truncated gene obtained by PCR was inserted into the E. coli/yeast shuttle vector 181A1NE (Riesmeier et al. 1992). DNA sequence analysis confirmed the presence of the yeast pho5 gene coding region. Expression of the PHO5 in this vector is driven by the constitutive alcohol dehydrogenase promoter recognized by the yeast transcription machinery. To cover all possible frames in clones coming from the cDNA library, two other vectors were also constructed containing one (pSDEP-1) and two (pSDEP-2) extra nucleotides (adenine) after the Bam HI site in the original vector pSDEP-0.

\section{BACTERIA AND YEAST TRANSFORMATION}

E. coli were transformed according to Hanahan (1993). Yeast transformation was done as described by Dohmen et al. (1991), with minor modifications.
After transformation, the yeast cells were grown for $3-4$ days at $28^{\circ} \mathrm{C}$ prior to staining.

\section{STAINING OF YEAST COLONIES AND}

SPECTROPHOTOMETRIC DETERMINATION OF ACID PHOSPHATASE ACTIVITY

The yeast colonies were stained for acid phosphatase activity as described by Dorn (1965) and To-E et al. (1973), with the addition of agarose (final concentration, $0.5 \%$ ) to avoid dislodging the colonies on the plate. Positive colonies remained viable for up to 30 min after the reaction and could be inoculated in liquid media for further analysis. Acid phosphatase activity was also determined spectrophotometrically (Sidhu and Bollon 1987).

\section{SCREENING FOR PHO5 ACTIVITY}

After transformation with plasmids containing unknown sequences inserted in front of the truncated pho5 in vectors pSDEP-0, 1 , and 2 as described above, aliquots of yeast cells were plated on minimal selective medium. The cells were grown as described and the staining solution was dropped on the colonies. After ten minutes red-colonies were detectable with the naked-eye. About 2000 colonies of transformed cells per plate were usually obtained by plating $20-50 \mu \mathrm{L}$ aliquots.

\section{ISOLATION OF CDNA 5'-ENDS VIA PCR}

AND CONSTRUCTION OF A SIGNAL SEQUENCE

SS-VECTOR LIBRARY

An oriented $\lambda$ ZAPII cDNA library previously established from potato leaf epidermal fragments highly enriched for guard cells (Kopka et al. 1997) was used as a source to clone genes from novel proteins destined for the secretory pathway. Complementary DNA fragments contained a NotI restriction site at their $5^{\prime}$-end and a XhoI restriction site at their $3^{\prime}$-end. Considering that signal sequences are located at the $5^{\prime}$-end of genes coding for membrane and secreted proteins, an enrichment for these sequences was obtained prior to inserting the sequences in front of the truncated pho5 gene. PCR reactions were done with $\mathrm{T} 3$ as the forward primer and a set of four degenerated oligonucleotides as 
reverse primers, each one 10 bases long and containing a Sau3A (BamHI compatible) restriction site at their $3^{\prime}$-end (SST1, 5'-CATGGWGATC; SST2, 5'-CAGTCWGATC; SST3, 5'-CAGTASGATC and SST4, 5'-CAGTTSGATC). The primers were designed to anneal randomly to internal regions of genes in the library and contained one wobble site (W or $\mathrm{S}$ ) to increase the variability of the combination. Alternatively, T3 and T7 were used as forward and reverse primers, respectively. After gel electrophoresis, the smear of fragments obtained was eluted and digested with NotI and Sau3A separately. With the latter restriction enzyme, reaction aliquots were withdrawn at different incubation times to provide greater variability in the fragment sizes. The digested fragments were ligated to the truncated yeast phosphatase in the pSDEP shuttle vectors 0,1 , and 2, and used for E. coli transformation to produce the signal sequence SS-vector library. All transformed cells were recovered by carefully harvesting the colonies grown on solid media and aliquots of a DNA maxi-preparation from these cells were used to transform yeast mutant cells prior to screening for PHO5 activity.

\section{SCREENING FOR FULL-LENGTH CLONES USING} THE $\lambda$ ZAPII CDNA LIBRARY

Approximately $5 \times 10^{5}$ plaque-forming units of a $\lambda$ ZAPII cDNA library established from potato leaf epidermal fragments were screened using the sequences retrieved in front of the truncated pho5 gene as probes. Radioactive labeling with $\left(\alpha-{ }^{32} \mathrm{P}\right) \mathrm{dCTP}$ (Amershan) was done using a random prime labeling kit from Boehringer Mannheim. Filters were hybridized overnight at $42^{\circ} \mathrm{C}$ in $250 \mathrm{mM}$ sodium phosphate buffer ( $\mathrm{pH} 7.2$ ) containing $7 \%$ SDS, $1 \%$ BSA and $1 \mathrm{mM}$ EDTA, and washed at $42^{\circ} \mathrm{C}$ in $5 \times$ SSC, $0.5 \%$ SDS, $5 \%$ formamide ( $20 \mathrm{~min}$ ) and in $3 \times$ SSC, $0.5 \%$ SDS (10 min). Plaque-purified phages were converted to pBluescript ${ }^{\circledR} S K$ derivatives by excision in vivo using the helper phage Exassist, according to the protocol provided by the manufacturer (Stratagene). Rescued phagemids were investigated by restriction analysis and DNA sequencing.

\section{Sequence Analysis}

DNA sequences were determined by the dideoxy method (Sanger et al. 1977).

\section{Northern Blot ANALYsis}

Potato plants grown in a greenhouse were used as a source of RNA. The plant material was frozen in liquid nitrogen and total RNA was extracted according to Logemann et al. (1987). RNA from epidermal fragments highly enriched for guard cells was obtained as previously described (Kopka et al. 1997). RNA gel electrophoresis and northern blot analysis were done as described elsewhere (Landschütze et al. 1995). Membranes were washed at $50^{\circ} \mathrm{C}$ in $3 \times$ SSC, $0.5 \%$ SDS ( $15 \mathrm{~min}$ ), followed by $1 \times \mathrm{SSC}$, $0.5 \%$ SDS (10 min).

Potassium ChanNel (KST1) PARTIAL SEQUENCES INSERTED in frame TO THE PHO5 GENE AS A MODEL FOR THE CHARACTERIZATION OF PHOSPHATASE ACTIVITY RELATIVE TO ITS POSITION IN THE CELL MEMBRANE

Partial sequences of the inward rectifying $\mathrm{K}^{+}$channel KST1 (Müller-Röber et al. 1995) were used to construct hybrid clones with the truncated acid phosphatase gene in the yeast vector for further characterization of PHO5 activity. Four clones were constructed, two positioning PHO5 inside the cell, and two positioning the enzyme outside the cell, depending on the number of intermembrane domain sequences inserted in front of pho5. The first 260 nucleotides located at the $5^{\prime}$-end of the KST1 clone (probably responsible for coding its signal sequence) and the signal sequence plus the first intermembrane domain from the spinach sucrose transporter were inserted in frame to the pho5 gene for comparison of the PHO5 activity in vivo. Yeast cells were transformed with the different constructs and plated as usual.

\section{RESULTS}

Prior to screening for secreted PHO5 directed by sequences from the cDNA library, the activity of the extracellular acid phosphatase coded by the se- 
quence obtained by PCR with primers $\mathrm{PHO} 1$ and PHO2 was tested by fusing a $200 \mathrm{bp}$ sequence containing the probable signal sequence of the sucrose transporter cloned from spinach (Riesmeier et al. 1992). This construction, referred to as 181A1NESTSS-PHO5, served as a positive control. The presence of characteristic red yeast colonies after staining showed that this $200 \mathrm{bp}$ fragment mimicked the original PHO5 signal peptide and led to the secretion of an active acid phosphatase by the yeast cell (Figure 1A). A five-minute preincubation of the yeast colonies with $0.1 \mathrm{M}$ sodium fluoride (an inhibitor of acid phosphatases) at $\mathrm{pH} 6.7$ inhibited the staining, thus confirming the involvement of an acid phosphatase in the reaction (data not shown).

That signal sequences other than those directing a polypeptide through the default pathway would not be detected by this model system was ascertained by fusing sequences in front of a truncated pho5 which could not lead the protein to the membrane or to the outside of the cell. Thus, the $\sim 99 \mathrm{bp}$ Asp718/BamHI fragment encoding the transit peptide of the potato mitochondrial matrix processing peptidase (Braun et al. 1992, Landschütze 1995), the $\sim 300$ bp Asp 718/BamHI fragment encoding the transit peptide of the potato plastidic ADP-glucose pyrophosphorylase large subunit (Müller-Röber et al. 1990), and the $\sim 200$ bp Not $/$ Bam HI fragment containing the $5^{\prime}$-end of the potato cytosolic phosphoenolpyruvate carboxylase (La Cognata 1996) were substituted for the sucrose transporter signal sequence in the vector 181A1NE-STSS PHO5. As expected, none of these produced a positive red staining for acid phosphatase (data not shown).

The signal sequence SS-vector library (see "Materials and Methods") containing the putative 5 '-end regions from the guard cell cDNA library inserted in front of the truncated pho5 reporter gene was used to transform YHH-33 mutant cells. After growing and screening for PHO5 activity, two colonies were isolated (clones YE139 and YE290), grown in liquid selective medium and replated for a second staining which was necessary to confirm and properly isolate the potential positive clone. These two sequences are indicated below.

\section{CLONE YE139}

5'- T ATT GTT TCT AAT TTT TTC CTA AAA TAA GCT AAG GCA ATT TAC CAC TCT TCA ATC ATA TCT GCA TCT GTT CTA TAT TGG TAT TGA GGT TCT GCC ATG ACA TTG TAC GGA CAA GCC ATC TTT CTG GGT TTC TTG ATC CTT pho5 -3'

This sequence shows one start codon (underlined ATG) in frame to the pho5 gene that served as an initiation codon and provided a signal sequence for $\mathrm{PHO} 5$ to reach the extracellular milieu. Before screening the guard cell cDNA library, a northern blot using RNA isolated from different potato tissues was done using this fragment as a probe to assure that the sequence came from the library and was not a PCR artifact. The result would also indicate the size of the original gene to be searched for in the library and thus, the size of the protein encoded. As depicted in Figure 1B, the highest levels of expression were found in green buds and stems, with considerable expression in roots and sink leaves. The full-size gene containing the sequence above would be about $3.5 \mathrm{kbp}$ long.

A sequence containing about $3.6 \mathrm{kbp}$ was retrieved after screening the guard cell cDNA library with clone YE139. Sequencing and restriction pattern analysis indicated a chimaeric clone, with the first $1.5 \mathrm{kbp}$ corresponding to an unknown protein and its second half to the $3^{\prime}$-end of plant cytochrome $\mathrm{P} 450$. As expected, the sequence from clone YE139 was found at the $5^{\prime}$-end of this unknown clone, indicating that it was responsible for encoding the signal sequence from this protein. Transforming YHH-33 yeast mutant cells again with YE139 confirmed the positive staining for acid phosphatase activity.

\section{CLONE YE290}

5'- TT CCA TTC AGT TTC CTT TAC TTG ATC GAA CAG CCC CAA ATT CAG TTA TTT CAA

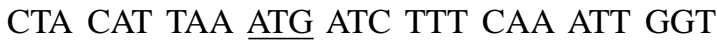
CAA GAC TCT CTA GTT TAT GGC CGC TTC TCT ATG GTA CCA GTT GTT GCT TCA TTG AAT TTG CTT CAC TAA TAG GCT CAC GCT TCG ACT TT*G ATC* CTG ATG AGC GTT TCT 

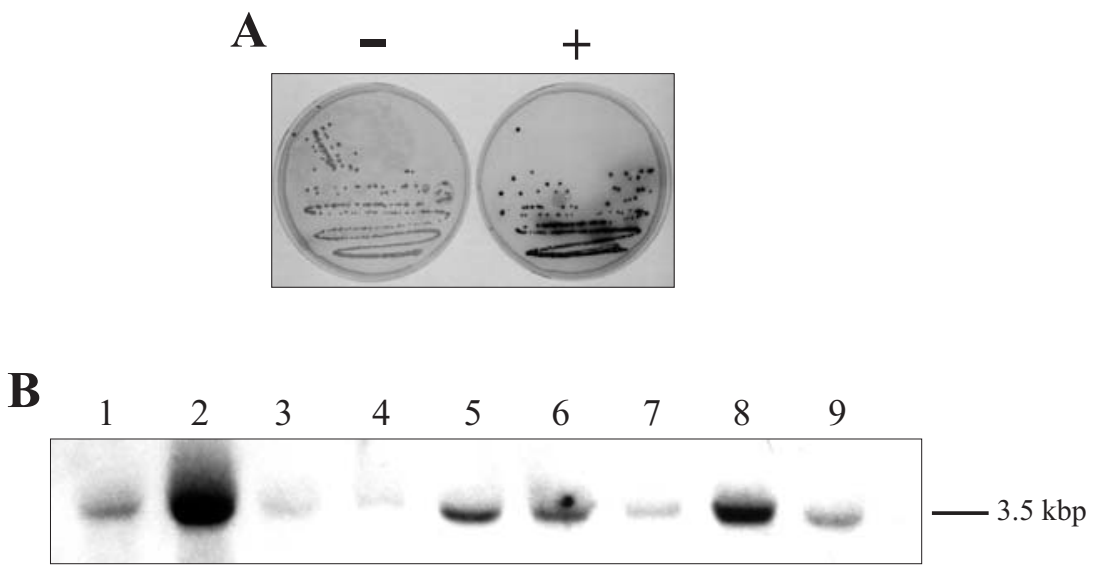

Fig. 1 - (A) YHH-33 yeast mutant cell colonies after staining for acid phosphatase PHO5 activity. Colonies on the right originated from cells transformed with vector 181A1NE-STSS-PHO5, where the spinach sucrose transporter signal sequence was inserted in frame to a truncated version of the pho5 acid phosphatase lacking its start codon and original signal sequence. Colonies on the left are from the same cell line transformed with vector 181A1NE containing only the truncated pho5 gene without its own or any other foreign signal sequence. PHO5-secreting cells (plate on the right) are stained red. (B) Expression pattern of sequence YE139 used as a probe in various tissues of potato plants. The transcript detected has a size of approximately $3.5 \mathrm{kbp}$. Total RNA was isolated from the following tissues: lane 1, coloured buds; lane 2, green buds; lane 3, epidermal fragments; lane 4, open flowers; lane 5, roots; lane 6, sink leaves; lane 7, source leaves; lane 8, stem; and lane 9, tubers. Amount of total RNA per lane about $30 \mu \mathrm{g}$.

TCG TGG ATT TTC GGG GTT TTG TTA GCT GGA ATA TGC AGT AGT GAT AAA CCC TAT ATG GAA CTG AGG AAA TCA GCT GAA TTG TTT GAT GAT TCT TTG ATC CTT pho5 -3'

This is a chimaeric sequence. The Sau3A cleavage site indicated between two asterisks marks the probable limits of two sequences after comparative analysis with known sequences in the Genebank. The upstream sequence showed homology to a plastidic protein, whereas the downstream sequence showed no significant homology to any known protein. One of the two start codons after this cleavage site and in frame to the truncated pho5 gene could be responsible for the enzyme secretion. The second half of this clone was amplified by PCR and cloned into pBluescript ${ }^{\circledR} S K$. Northern blot using this sequence as a probe indicated a $3 \mathrm{kbp}$ gene being differentially expressed primarily in floral parts (androceum and gyneceum) and roots (Figure 2). Significant expression could also be observed in green buds and epidermal fragments.

A sequence of about $720 \mathrm{bp}$ and containing part of the sequence used as a probe was retrieved after screening the cDNA library again. This sequence also showed no homology to known proteins.

Because of the low efficiency in recovering potential sequences other than chimaeric ones directing $\mathrm{PHO} 5$ to the outside of the cell, we examined whether extracellularly located but membranebound PHO5 would interact with the staining reagents and give a positive result, or whether PHO5 must be sterically free to provide positive staining. Hybrid genes were constructed coding for one or more transmembrane domains from the inward rectifying $\mathrm{K}^{+}$channel KST1 fused in frame to the truncated pho5, thereby positioning the acid phosphatase to the cell interior or exterior. After transformation and growth, none of the supposedly positive clones (those expressing PHO5 bound to the outside of the cell) showed the expected red staining. In contrast to the positive staining obtained with the signal sequence from the spinach sucrose transporter, the construct encoding only the probable signal sequence from KST1 in frame to the phosphatase did not stain red. However, all transformants showed 


\begin{tabular}{|c|c|c|c|c|c|}
\hline 1 & 2 & 3 & 4 & 5 & 6 \\
\hline & & & & . & \\
\hline
\end{tabular}

Fig. 2 - Expression pattern of the 3 '-end of sequence YE290 used as a probe in various tissues of potato plants. The transcript detected has a size of approximately $3.0 \mathrm{kbp}$. Total RNA was isolated from the following tissues: lane 1, androceum; lane 2, gyneceum; lane 3 , coloured buds; lane 4, green buds; lane 5, epidermal fragments; lane 6, sink leaves; lane 7, source leaves; lane 8, roots. Amount of total RNA per lane about $30 \mu \mathrm{g}$.

positive acid phosphatase activity after cell disruption compared to the low activity obtained with YHH-33 mutant cells containing the vector without insert (Figure 3). Another hybrid protein was constructed using the spinach sucrose transporter. Here, in addition to the signal sequence, the first transmembrane domain sequence was also cloned in frame to the acid phosphatase gene. This was expected to produce a hybrid protein in which $\mathrm{PHO} 5$ would face the outside of the cell. Again, no acid phosphatase activity was detected by direct staining of the colonies, although activity was seen after disruption of the cells (Figure 3).

\section{DISCUSSION}

The functionality of the SST-system was demonstrated by inserting the signal sequence from a known membrane protein (sucrose transporter from spinach) and later by retrieving two unknown sequences from a guard cell cDNA library showing strong tissue-specific expression.

Among the various problems encountered during the development of the SST-system, the recombination of fragments obtained after NotI and Sau3A digestion, and the formation of chimaeric sequences as a consequence of such recombinations, were unsolved. The chimaeric sequences were produced by linking fragments of different sizes containing the Sau3A cleavage site at both ends, so that the final product would have a NotI site at the $5^{\prime}$-end, as expected, followed by many shorter sequences of joined Sau3A-Sau3A fragments.

An attempt to improve the yield of nonchimaeric sequences involved the use of a biotiny- lated $\mathrm{T} 3$ as a $5^{\prime}$-end primer for the generation of PCR fragments, together with $\mathrm{T} 7$, a mixture of degenerated 10mers as described in "Materials and Methods", or primers containing only a BamHI cleavage site at their $3^{\prime}$-end. The PCR fragments thus obtained were cleaved with Sau3A and aliquots were withdrawn after different incubation periods. These aliquots were treated with streptavidin-coated beads, so that fragments with only one Sau3A cleavage site at their 3 -ends would be retained. These fragments would then be retrieved by washing the beads with appropriate buffers, and further cleavage with NotI would give the expected NotI-Sau3A fragments to be cloned in front of the pho5 gene in the vector pSDEP. Since this procedure resulted in a dramatic decrease in the number of yeast colonies grown after transformation (only 2-6 colonies/plate), these experiments were discontinued. None of the modifications introduced resulted in the exclusive insertion of 5'-ends originating from single cDNA clones. Although other sequences retrieved from the cDNA library also led to the secretion of acid phosphatase, for most of these it was not possible to demonstrate exactly which segment was responsible for the secretion, because of the high recombination rates for sequences containing Sau3A restriction sites at both ends and the consequent formation of chimaeras. As shown elsewhere, up to $25 \%$ of randomly generated peptides can function as signal sequences for the ER, mitochondria, and bacterial plasma membrane (Schatz and Dobberstein 1996). Interestingly, the sequence of the $5^{\prime}$-end region of $\beta$-lactamase was also retrieved after screening for PHO5 activity and probably resulted from digestion of the shuttle vector used during cloning. 


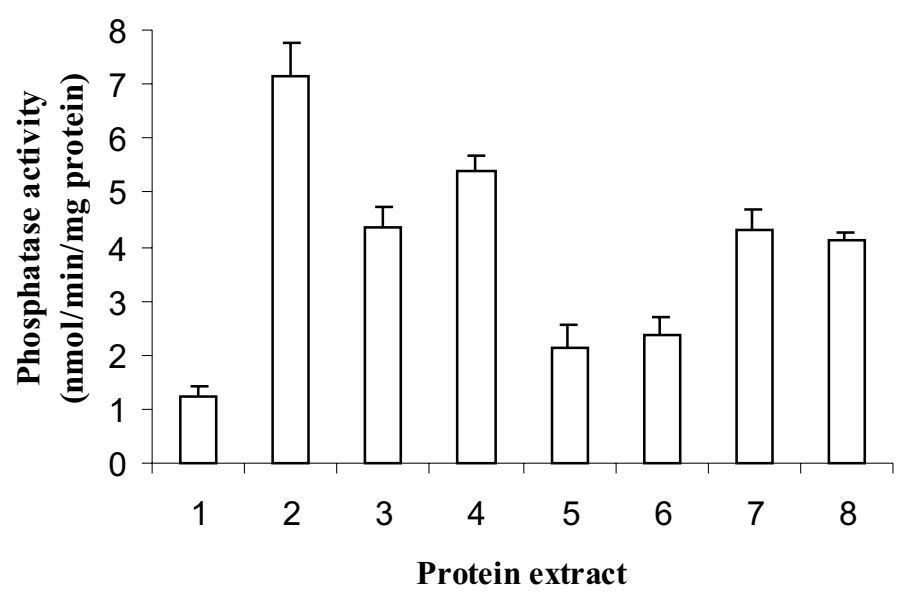

Fig. 3 - Spectrophotometric measurements of phosphatase activity in protein extracts from YHH-33 yeast cells transformed with constructs coding for different hybrid proteins of the spinach sucrose transporter, KST1, and acid phosphatase. Protein extract from 2 came from cells containing vector 181A1NE-STSS-PHO5 and showed maximum acid phosphatase activity. Hybrid proteins from extracts 3 and 5 were designed to position PHO5 outside the cell, between subdomains 1-2 and 3-4 of the six-membrane spanning domains of protein KST1, respectively. Hybrid proteins from extracts 4 and 6 were designed to position PHO5 facing the cytosol between subdomain 2-3 and 4-5 of KST1, respectively. Extract 7 harbours the hybrid protein coded by the sequence containing pho5 in frame to the first $260 \mathrm{bp}$ of KST1 thought to possess the signal sequence, while extract 8 codes for PHO5 facing the cell exterior linked to the first intermembrane domain of the spinach sucrose transporter. Protein extract from 1 was obtained from YHH-33 cells transformed with yeast vector 181A1NE only and represents the background acid phosphatase activity (PHO3, PHO10, constitutively expressed at a very low concentration). Assays were done with three different colonies from each construct.

Further experiments using the potassium channel KST1 gene as a model revealed other uncertainties not considered at the beginning of this work. Among these, that the position of the acid phosphatase relative to the cell membrane might play a decisive role in its catalytic activity and influence the detection of positive clones. A similar effect caused by immobilization of lipase on the surface of yeast cells has already been described (Schreuder et al. 1996). When the acid phosphatase was linked to the plasma membrane via one or more transmembrane domains of the KST1 protein, its enzymatic activity was detected only in extracts of these cells. These findings were corroborated by comparing the enzymatic activity of acid phosphatase fused to the spinach sucrose transporter signal sequence free in the periplasmic space, which was positive, with the activity of an enzyme anchored in the plasma mem- brane by one of its transmembrane domains, which gave negative staining. That the probable signal sequence from KST1 was not able to direct the acid phosphatase to outside the cell was a surprise, but not necessarily unexpected. It may be argued that while the general mechanisms of signal sequence recognition between yeast (S. cerevisiae) and plants $(S$. tuberosum) are basically the same, there are subtle variations. Thus, the position of acid phosphatase relative to the cell membrane, and signal sequence recognition among different eukaryotes could have affected the retrieval of positive clones, even if chimaeric sequences were not the main problem.

Other reports have described signal sequence traps (Skarnes et al. 1995, Yokoyama-Kobayashi et al. 1995), but only one (Klein et al. 1996) has yielded few drawbacks. The excellent results obtained by Klein and coworkers probably reflected the fact that 
their system involved only mutant complementation on a selective medium rather than a direct screening procedure. Although $\mathrm{PHO} 5$ yeast mutants were used in our system, the screening involved staining as well as mutant complementation. Besides, those authors used a human cDNA library for constructing the vectors for the transformation of yeast cells.

These and other differences in the ability of yeasts in handling plant and animal proteins may account for some of the variations reported in signal sequence trap studies.

\section{ACKNOWLEDGMENTS}

The authors thank R. Breitfeld, B. Burose, and T. Mieland for caring for the greenhouse plants, and A. Voigt and J. Bergstein for photographic work. M. J. S. was the recipient of a doctoral fellowship from $\mathrm{CNPq}$ (Conselho Nacional de Desenvolvimento Científico e Tecnológico, Brazil). Part of this work was supported by a Deutsche Forschungsgemeinschaft grant to B. M.-R.

\section{RESUMO}

$\mathrm{O}$ direcionamento de proteínas a organelas e à membrana celular, ou de proteínas a serem secretadas, é coordenado por seqüências sinalizadoras localizadas na extremidade $5^{\prime}$ de seus respectivos genes que codificam peptídeossinal. Este trabalho analisa um sistema para seleção de sequiências sinalizadoras utilizando uma fosfatase ácida de levedura, enzima reconhecidamente secretada por estes organismos, desprovida de seu códon de iniciação e de sua seqüência sinalizadora, como gene repórter. Uma fração enriquecida em fragmentos provenientes da região $5^{\prime}$ de uma biblioteca de cDNA de células-guarda de batata foi inserida in frame ao gene truncado da fosfatase ácida em vetores apropriados. Após a transformação em leveduras, a atividade da fosfatase ácida foi medida diretamente sobre colônias crescidas em meio seletivo. A seqüência nucleotídica dos prováveis peptídeos-sinal capazes de direcionar aquela enzima ao exterior celular foram utilizadas como sondas para recuperação da seqüência original da biblioteca de cDNA. Dois clones sem homologia conhecida, mas apresentando forte expressão tecido-específica, foram obtidos, um deles (YE139) com expressão acen- tuada em botões florais verdes e células do tronco, e o outro (YE290) de expressão elevada em androceu, gineceu e raízes. Os diversos problemas encontrados durante a execução do trabalho são discutidos face aos resultados obtidos com outras proteínas-modelo.

Palavras-chave: sequiências sinalizadoras, canal de potássio, fosfatase ácida de levedura, triagem de biblioteca de cDNA.

\section{REFERENCES}

Arima K, Oshima T, Kubota I, Nakamura N, MizunaGA T AND ToH-E A. 1983. The nucleotide sequence of the yeast pho5 gene: a putative precursor of repressible acid phosphatase contains a signal peptide. Nucl Acids Res 11: 1657-1672.

Blobel G And Dobberstein B. 1975. Transfer of proteins across membranes. I. Presence of proteolytically processed and non-processed nascent immunoglobulin chains on membrane bound ribosomes of murine melanoma. J Cell Biol 67: 835-851.

Braun H-P, Emmermann M, Kruft V and Schmitz UK. 1992. The general mitochondrial processing peptidase from potato is an integral part of the cytochrome $\mathrm{c}$ reductase of the respiratory chain. EMBO J 11: 3219-3227.

Dohmen RJ, Strasser AW, Honer CB and HollenBER CP. 1991. An efficient transformation procedure enabling long-term storage of competent cells of various yeast genera. Yeast 7: 691-692.

DoRN G. 1965. Genetic analysis of the phosphatases in Aspergillus nidulans. Genet Res, Camb 6: 13-26.

Hadlington JL and Denecke J. 2000. Sorting of soluble proteins in the secretory pathway of plants. Curr Opin Plant Biol 3: 461-468.

HANAHAN D. 1983. Studies on transformation of bacteria with plasmids. J Mol Biol 166: 557-580.

KLein RD, Gu Q, Goddard A and Rosenthal A. 1996. Selection for genes encoding secreted proteins and receptors. Proc Natl Acad Sci USA 93: 7108-7113.

Kopka J, Provart NJ and Müller-Röber B. 1997. Potato guard cells respond to drying soil by a complex change in the expression of genes related to carbon metabolism and turgor regulation. Plant J 11: 871882.

La Cognata U, Landschütze V, Willmitzer L and MÜLLER-RÖBER B. 1996. Structure and expression 
of mitochondrial citrate synthases from higher plants. Plant Cell Physiol 37: 1022-1029.

LANDSchütze V, WiLlmitzer L AND MÜLleR-RöBeR B. 1995. Inhibition of flower formation by antisense repression of mitochondrial citrate synthase in transgenic potato plants leads to a specific disintegration of the ovary tissues of flowers. EMBO J 14: 660-666.

LogemanN J, Schell J AND Willmitzer L. 1987. Improved method for isolation of RNA from plant tissues. Anal Biochem 163: 21-26.

Lopandic K, Deana AD, Barbaric S and Pinna LA. 1987. Biochemical and genetic evidence that yeast extracellular protein phosphatase activity is due to acid phosphatase. Biochem Int 14: 627-633.

Masson F And Rossignol M. 1995. Basic plasticity of protein expression in tobacco leaf plasma membrane. Plant J 8: 77-85.

Milstein C, Brownlee GG, Harrison TM AND Matthews MB. 1982. A possible precursor of immunoglobulin light chains. Nature New Biol 239: 117-120.

Müller-Röber B, Kossmann J, Hannah LC, WillMITZER L AND SONNEWALD U. 1990. One of two different ADP-glucose pyrophosphorylase genes from potato responds strongly to elevated levels of sucrose. Mol Gen Genet 224: 136-146.

Müller-Röber B, Ellenberg J, Provart NJ, Willmitzer L, Busch H, Becker D, Dietrich P, Hoth S AND Hedrich R. 1995. Cloning and electrophysiological analysis of KST1, an inward rectifying $\mathrm{K}^{+}$ channel expressed in potato guard cells. EMBO J 14: 2409-2416.

Oshima Y. 1997. The phosphatase system in Saccharomyces cerevisiae. Genes Genet Syst 6: 323-334.

Riesmeier JW, Willmitzer L AND Frommer WB. 1992. Isolation and characterization of a sucrose carrier cDNA from spinach functional expression in yeast. EMBO J 11: 4705-4713.
Rose MD, Winston F AND Hieter P. 1990. Isolation of genomic DNA from Saccharomyces cerevisiae. In Methods in Yeast Genetics, CSHL Press, Cold Spring Harbor, New York, p. 126-127.

Sambrook J, Fritsch EF and Maniatis T. 1989. Molecular cloning: a laboratory manual. Second edition, CSHL Press, Cold Spring Harbor, New York.

SANGer F, Nicklen S ANd Coulson AR. 1977. DNA sequencing with chain-terminating inhibitors. Proc Natl Acad Sci USA 74: 5463-5467.

Schatz G ANd Dobberstein B. 1996. Common principles of protein translocation across membranes. Science 271: 1519-1526.

Schreuder MP, MoOren AT, ToschKa HY, Verrips CT AND KLIS FM. 1996. Immobilizing proteins on the surface of yeast cells. Trends Biotechnol 14: 115120.

SIDHu RS AND Bollon A. 1987. Analysis of alpha-factor secretion signals by fusing with acid phosphatase of yeast. Gene 54: 175-184.

Skarnes WC, Moss JE, Hurtley SM and Beddington RSP. 1995. Capturing genes encoding membrane and secreted proteins important for mouse development. Proc Natl Acad Sci USA 92: 6592-6596.

Sмiтн H. 1990. Signal perception, differential expression within multigene families and the molecular basis of phenotypic plasticity. Plant Cell Environ 13: 585594.

To-E A, UedA Y, KaKimoto SI And Oshima Y. 1973. Isolation and characterization of acid phosphatase mutants in Saccharomyces cerevisiae. J Bacteriol 113: 727-738.

Yokoyama-Kobayashi M, Sugano S, Kato T and Kato S. 1995. A signal sequence detection system using secreted protease activity as an indicator. Gene 163: 193-196. 